\title{
KARAKTERISTIK HABITAT FAMILI CARANGIDAE DI PADANG LAMUN KOTA BONTANG-INDONESIA
}

\author{
Aditya Irawan ${ }^{a *}$, Jailani $^{\mathrm{b}}$ dan Lily Inderia Sari ${ }^{\mathrm{a}}$ \\ aProgram Studi Pengelolaan Sumberdaya Perikanan FPIK Universitas Mulawarman, Jl. Gunung \\ Tabur No.1. Kampus Gunung Kelua Samarinda, Indonesia \\ bLaboratorium Bioekologi Jurusan Manajemen Sumberdaya Perairan FPIK Universitas \\ Mulawarman, Jl. Gunung Tabur No.1. Kampus Gunung Kelua Samarinda,Indonesia
}

*Koresponden penulis: aditya.irawan@fpik.unmul.ac.id

\begin{abstract}
Abstrak
Asosiasi padang lamun dengan muara sungai maupun ekosistem pesisir lainnya memberikan karakteristik yang khas terhadap terbentuknya habitat lamun dan interaksi spesies ikan dengan padang lamun. Tujuan penelitian adalah mengetahui karakteristik habitat dari famili Carangidae di padang lamun pesisir Kota Bontang. Penelitian dilaksanakan pada bulan Maret hingga Desember 2020. Pengambilan sampel ikan dari famili Carangidae dilakukan berdasarkan hasil tangkapan alat tangkap trap net (belat : nama lokal). Pengambilan sampel lamun dilakukan dengan metode transek dan pengambilan sampel kualitas air dilakukan secara in situ. Analisis karakteristik habitat, speises dari Carangidae digunakan Correspondence Analysis dan korelasi Pearson Moment Product, karakteristik sebaran spasial variabel kualitas air digunakan Principal Component Analisis. Enhalus acoroides dan Cymodocea ratundata merupakan spesies dominan dalam menyusun padang lamun. Selaroides leptolepis dan Scomberoides tala merupakan spesies yang dominan berasosiasi di padang lamun. Karakteristik spesies lamun menyusun padang lamun memberikan relung ekologis bagi spesies dari Carangidae dalam fase biologinya.
\end{abstract}

Kata kunci: carangidae, lamun, relung ekologi,

\begin{abstract}
The association of seagrass beds with river estuaries and other coastal ecosystems provides unique characteristics for the formation of seagrass habitats and the interaction of fish species with seagrass beds. The purpose of the study was to determine the habitat characteristics of the Carangidae family in the coastal seagrass beds of Bontang City. The study was carried out from March to December 2020. Sampling of fish from the Carangidae family was carried out based on the catch of the trap net fishing gear (belat: local name). Seagrass sampling was carried out using the transect method and water quality sampling was carried out in situ. Analysis of habitat characteristics, species of Carangidae used Correspondence Analysis and Pearson Moment Product correlation, spatial distribution characteristics of water quality variables used Principal Component Analysis. Enhalus acoroides and Cymodocea ratundata are the dominant species in the composition of seagrass beds. Selaroides leptolepis and Scomberoides tala are the dominant species associated in seagrass beds. Characteristics of seagrass species that make up seagrass beds provide an niche for species of Carangidae in their biological phase.
\end{abstract}

Keywords: carangidae, niche, seagrass. 


\section{PENDAHULUAN}

Padang lamun yang berasosiasi dengan muara sungai dan ekosistem pesisir memberikan karakteristik yang khas terhadap terbentuknya habitat lamun dan interaksi spesies ikan dengan padang lamun tersebut [1][2][3]. Padang lamun sebagai habitat memberikan kontribusi sebagai daerah asuhan, mencari makan maupun sebagai tempat berlindung untuk berbagai biota perairan [4][5][6][7][8]. Umumnya ikan yang berasosiasi di padang lamun bukan hanya ikan yang menjadikannya sebagai habitat utamanya, namun ditemukan pula kelompok ikan-ikan predator yang menjadikan padang lamun sebagai tempat mencari makan [9]. Kelompok ikan yang berasosiasi merupakan ikan yang bernilai ekonomis tinggi [10] dan diantaranya dari famili Carangidae [11].

Spesies dari famili Carangidae merupakan ikan yang hidup bergerombol, bernilai ekonomis tinggi dan merupakan ikan target penangkapan [12]. Famili Carangidae terdiri dari 30 genera 148 spesies dan merupakan ikan karnivora perenang cepat dan menjadikan ikan-ikan predator menjadi mangsanya [11] serta memiliki sebaran yang luas hingga ditemukan di Samudra Atlantik, India, dan Pasifik [12][13].

Habitat dari famili ini ditemukan di perairan estuaria [14] terutama pada fase premature sedangkan fase dewasa ditemukan di perairan pesisir, pelagis hingga lepas pantai [15] dan memijah di perairan pesisir hingga perairan payau [12]. Beberapa spesies ditemukan di terumbu karang [16] dan padang lamun [17]. Spesies dari famili Carangidae ditemukan pula di padang lamun pesisir Kota Bontang dan merupakan target penangkapan oleh nelayan setempat [9]. Kehadirannya di padang lamun menunjuk-kan adanya asosiasi terhadap karakteristik padang lamun sebagai habitatnya, atau karakteristik spesies lamun yang menyusun padang lamun menyediakan relung-ekologis (niche) bagi spesies ikan setiap fase siklus biologinya ([17]. Berkaitan dengan hal tersebut pentingnya untuk mengkaji karak-teristik habitat famili Carangidae di padang lamun di perairan pesisir Kota Bontang sebagai upaya menjaga kelestarian sumber-daya ikan di ekosistem padang lamun.

\section{METODE}

Penelitian ini dilaksanakan di padang lamun perairan pesisir utara Kota Bontang (Gambar 1) mulai bulan Maret - Desember 2020. Penelitian ini dilakukan dengan pendekatan observasi/survei lapangan dengan menentukan terlebih dahulu stasiun penelitian.

Stasiun penelitian terbagi menjadi 4 stasiun, yaitu stasiun yang difokuskan untuk mengetahui komposisi dan jumlah individu spesies dari famili Carangidae dan kondisi aktual padang lamun serta lingkungannya. Adapun gambaran umum keempat stasiun tersebut, yaitu : Stasiun A yaitu padang lamun yang berada di Karang Kiampau yang berasosiasi dengan muara sungai Tanjung Limau, hutan mangrove dan terumbu karang; Stasiun B yaitu padang lamun yang berada di P. Badak-Badak yang berasosiasi dengan hutan mangrove, Stasiun C : padang lamun yang berada di Sapa Segajah yang berasosiasi dengan terumbu karang, dan Stasiun D : padang lamun yang berada di Muara Sungai Bontang Kuala.

Pengambilan sampel ikan dari famili Carangidae dilakukan berdasarkan hasil tangkapan alat tangkap trap net (belat : nama lokal) [17], kemudian diukur panjang total ikan dan berat. Pengambilan sampel dilakukan sebanyak tiga kali, adapun periode pengambilan sampel selama 30 hari. Pengelompokan berdasarkan proposi yuwana melalui ukuran ikan yang tertangkap dengan membandingkan ukuran ikan yang sejenis, umumnya ikan yang berukuran lebih kecil dari ukuran rata-rata ikan sejenis dimasukkan dalam kategori mature [18].

Pengambilan sampel lamun untuk masing-masing stasiun terdiri dari 3 transek pada kedalaman yang berbeda yaitu pada batas pasang tertinggi dan pada batas surut terendah. Adapun pengambilan sampel lamun dilakukan sebanyak 3 kali dengan periode pengambilan sampel 30 hari. Penga-matan secara visual dan penghitungan jumlah tegakan spesies lamun yang terdapat dalam setiap petak berukuran $0,5 \times 0,5 \mathrm{~m}$ [19] dan contoh spesies kemudian diidentifikasi berasarkan [20][21][22][23] kemudian dilakukan perhitungan kerapatan mutlak dan kerapatan relatif (KR) [19]. 
Pengambilan data kualitas air (suhu, salinitas, $\mathrm{pH}$ dan kekeruhan) dilakukan secara in situ (pengukuran langsung dilapangan) dengan menggunakan Water quality checker. Mendeterminasi sebaran karak-teristik fisikakimia air antara stasiun penelitian digunakan suatu pendekatan analisis statistika multi variabel yang didasarkan pada Principal Component Analisis/PCA [24]. Sebaran komunitas lamun pada stasiun penelitian dan asosiasi dari spesies famili Carangidae dengan karakteristik habitat menggunakan Correspondence Analysis/CA [24]. Mendeterminasi hubungan antara kerapatan tegakan lamun

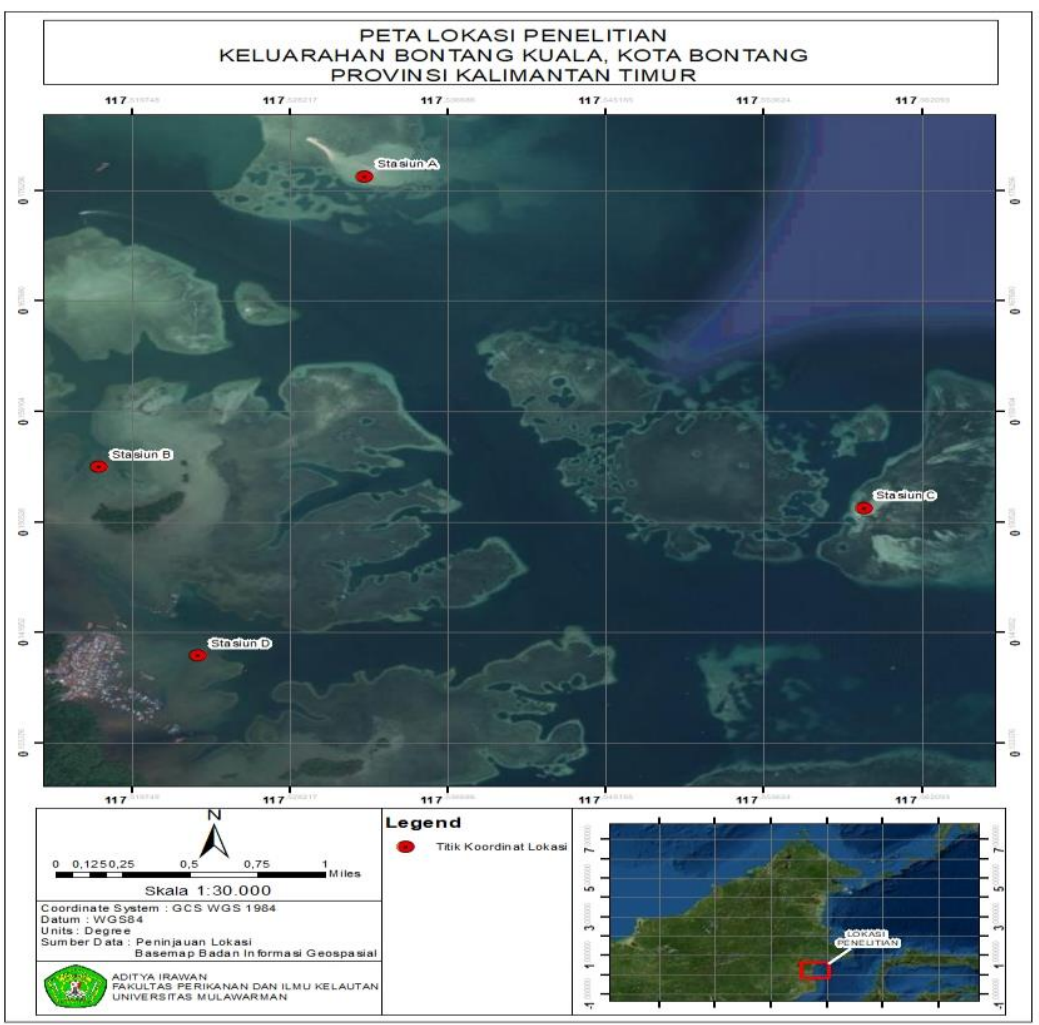

Gambar 1. Peta lokasi penelitian

dengan jumlah individu spesies dari famili Carangidae dan hubungan antar spesies digunakan uji statistika korelasi Pearson Moment Product [25][26][27].

\section{HASIL DAN PEMBAHASAN}

\section{Lamun}

Padang lamun disusun oleh 5 spesies yang terdiri dari Enhalus acoroides, Cymodocea ratundata, Thalassia. hemprichii, Halodule pinifolia, dan Halophila minor (Tabel 2). Berdasarakan Tabel 2 menunjukkan bahwa kerapatan lamun berkisar 157 - 627 tegakan $/ \mathrm{m}^{2}$ dengan rata-rata $335 \pm 0,98$ tegakan $/ \mathrm{m}^{2}$ dan masing-masing stasiun memiliki fluktuasi kerapatan yang relatif kecil. Berdasarkan komposisi dan kerapatan lamun menunjukkan bahwa Stasiun A memiliki komposisi spesies paling banyak dan kerapatan yang paling tinggi, hal tersebut menunjukkan pula keanekaragaman spesies dan kerapatan cenderung menurun semakin ke selatan.

Kerapatan relatif tertinggi spesies lamun di Stasiun A yaitu $C$. ratundata kemudian $H$. pinifolia, E. acoroides, $H$. minor dan $T$. hemprichii. Stasiun B yaitu $C$. ratundata kemudian $E$. acoroides, demikian pula pada Stasiun $\mathrm{C}$ kerapatan relatif tertinggi yaitu $C$. ratundata kemudian $E$. acoroides dan $T$. hemprichii, sedangkan pada Stasiun D 
Tabel 1. Komposisi, kerapatan spesies lamun berdasarkan stasiun

\begin{tabular}{|c|c|c|c|c|}
\hline \multirow{2}{*}{ Spesies } & Stasiun A & Stasiun B & Stasiun $\mathrm{C}$ & Stasiun D \\
\hline & Kisaran Rerata $( \pm S D)$ & Kisaran Rerata $( \pm S D)$ & Kisaran Rerata $( \pm S D)$ & Kisaran Rerata $( \pm S D)$ \\
\hline E. acoroides & $123-124 \quad 123 \pm 0,58$ & $130-131 \quad 131 \pm 1,15$ & $73 \pm 0,58$ & $157 \pm 0,0$ \\
\hline C. ratundata & $150-153 \quad 151 \pm 1,73$ & $255-259257 \pm 2,08$ & $42 \pm 0,58$ & \\
\hline T. hemprichii & $87 \pm 2,08$ & & $53 \pm 0,58$ & \\
\hline H. pinifolia & $143-144 \quad 144 \pm 0,58$ & & & \\
\hline H. minor & $120-125 \quad 123 \pm 2,89$ & & & \\
\hline Jumlah & $627 \pm 1,57$ & $388 \pm 0,65$ & $168 \pm 1,73$ & $157 \pm 0,00$ \\
\hline
\end{tabular}

kerapatan relatif tertinggi yaitu E. acoroides (Gambar 2). Berdasarkan persentasi kerapatan relatif masing-masing spesies menunjukkan bahwa kerapatan relatif rata-rata tertinggi seluruh stasiun adalah E. acoroides mencapai 47,5\%, kemudian $C$. ratundata mencapai $42,3 \%, H$. pinifolia mencapai $23 \%, T$. hemprichii mencapai $20,3 \%$ dan $H$. minor mencapai $19,5 \%$. Kondisi demikian menunjukkan bahwa $E$. acoroides dan $C$. ratundata merupakan spesies dominan dalam menyusun padang lamun di bagian utara padang lamun Kota Bontang.

\section{Sebaran Spesies Lamun}

Berdasarkan sebaran spesies lamun menunjukkan bahwa E. acoroides tersebar di empat stasiun dengan kisaran kerapatan 73 157 tegakan $/ \mathrm{m}^{2}$ dengan rata-rata $121 \pm 0,58$ tegakan $/ \mathrm{m}^{2}$ (Tabel 2). Kerapatan tertinggi $E$. acoroides ditemukan di Stasiun D $(157 \pm 0,0)$ dan kerapatannya semakin menurun sejalan dengan semakin meningkatnya komposisi spesies lamun yang menyusun padang lamun di setiap stasiun dan fluktuasi kerapatan $E$. acoroides cenderung stabil. Demikian pula kerapatan $C$. ratundata tersebar di tiga stasiun dengan kisaran kerapatan $41-259$ tegakan $/ \mathrm{m}^{2}$ dengan rata-rata $150 \pm 1,46$ tegakan $/ \mathrm{m}^{2}$. Kerapatan tertinggi $C$. ratundata ditemukan di Stasiun B $\left(257 \pm 2,08\right.$ tegakan $\left./ \mathrm{m}^{2}\right)$ dan kerapatan terendah ditemukan di Stasiun C $\left(42 \pm 0,58\right.$ tegakan $\left./ \mathrm{m}^{2}\right)$ dengan fluktuasi kerapatan masing-masing stasiun cenderung stabil. Kemudian kerapatan T. hemprichii ditemukan di dua stasiun, yaitu Stasiun A dan Stasiun $\mathrm{C}$ dengan masing-masing kerapatan rata-rata $87( \pm 2,08)$ tegakan $/ \mathrm{m}^{2}$ dan $53 \pm 0,58$ tegakan $/ \mathrm{m}^{2}$ dengan fluktuasi kerapatan masing-masing stasiun cenderung stabil (kerapatan rata-rata : 70 $\pm 1,33$ tegakan $/ \mathrm{m}^{2}$ ). Berbeda halnya sebaran $H$. pinifolia, dan $H$. minor hanya ditemukan di Stasiun A dengan kerapatan rata-rata berturut-turut $144( \pm 0,58)$ tegakan $/ \mathrm{m}^{2}$ dan $123( \pm 2,89)$ tegakan $/ \mathrm{m}^{2}$ (Tabel 2) dengan fluktuasi kerapatan masing-masing stasiun cenderung stabil.

Berdasarkan Gambar 3 menunjukkan

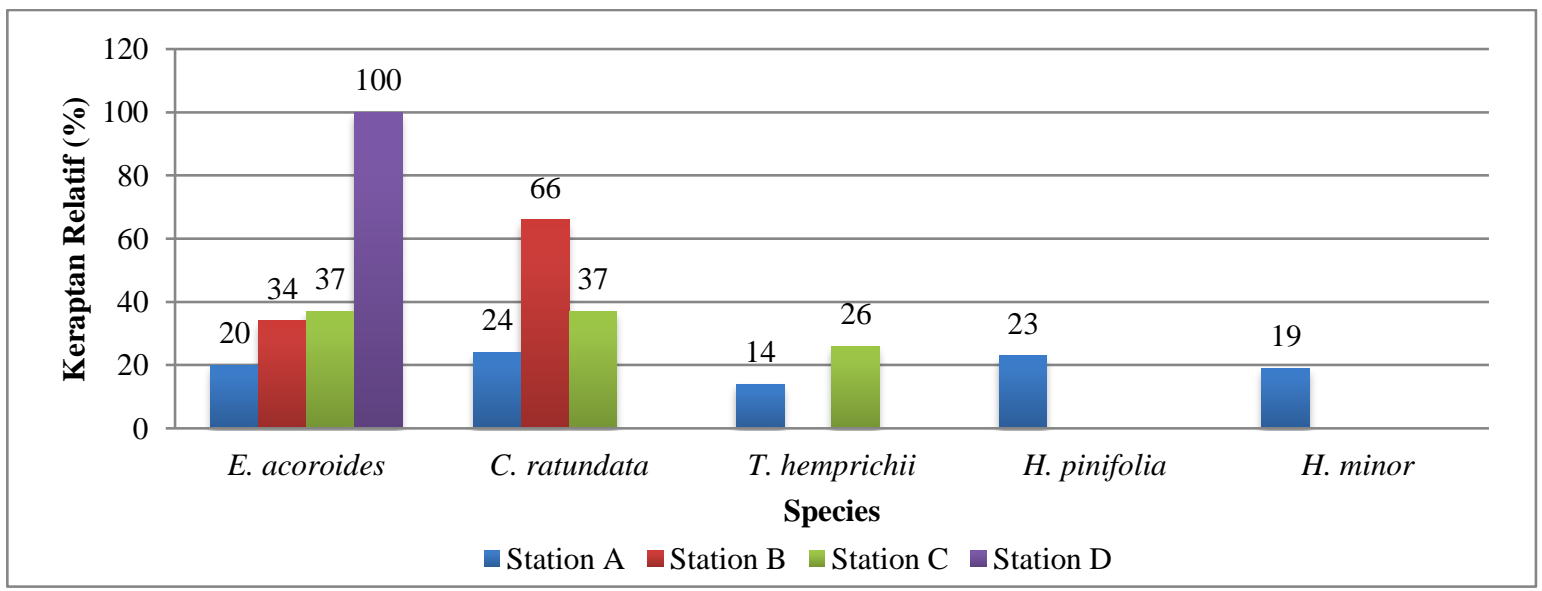

Gambar 2. Kerapatan relatif spesies lamun berdasarkan stasiun.

sebaran kerapatan spesies lamun berdasarkan stasiun yang terinformasi sebesar $100 \%$ yang terdiri dari Dimensi 1 sebesar 56,18\%,
Dimensi 2 sebesar 32,34 \% dan Dimensi 3 sebesar $11,47 \%$, yang menunjukkan bahwa $H$. pinifolia dan $H$. minor berasosiasi erat 
dengan karakteristik Stasiun A, C. ratundata berasosiasi erat dengan Stasiun $\mathrm{B}, T$. hemprichii berasosiasi erat dengan karakteristik Stasiun C, dan E. acoroides berasosiasi erat dengan karakteristik Stasiun D.

\section{Carangidae}

\section{Komposisi dan Jumlah Individu}

Spesies dari famili Carangidae yang ditemukan di padang lamun di bagian utara pesisir Kota Bontang terdiri dari 9 spesies yang terbagi dalam 7 genera (Tabel 2), hal tersebut menunjukkan bahwa wilayah ini memiliki 23,3\% dari total genera dan 6,08\% dari total spesies yang ditemukan di dunia [15][28]. Berdasarkan jumlah individu menunjukkan bahwa genera Carangoides memiliki persentase yang paling tinggi kemudian Selaroides, Selar, Scomberoides

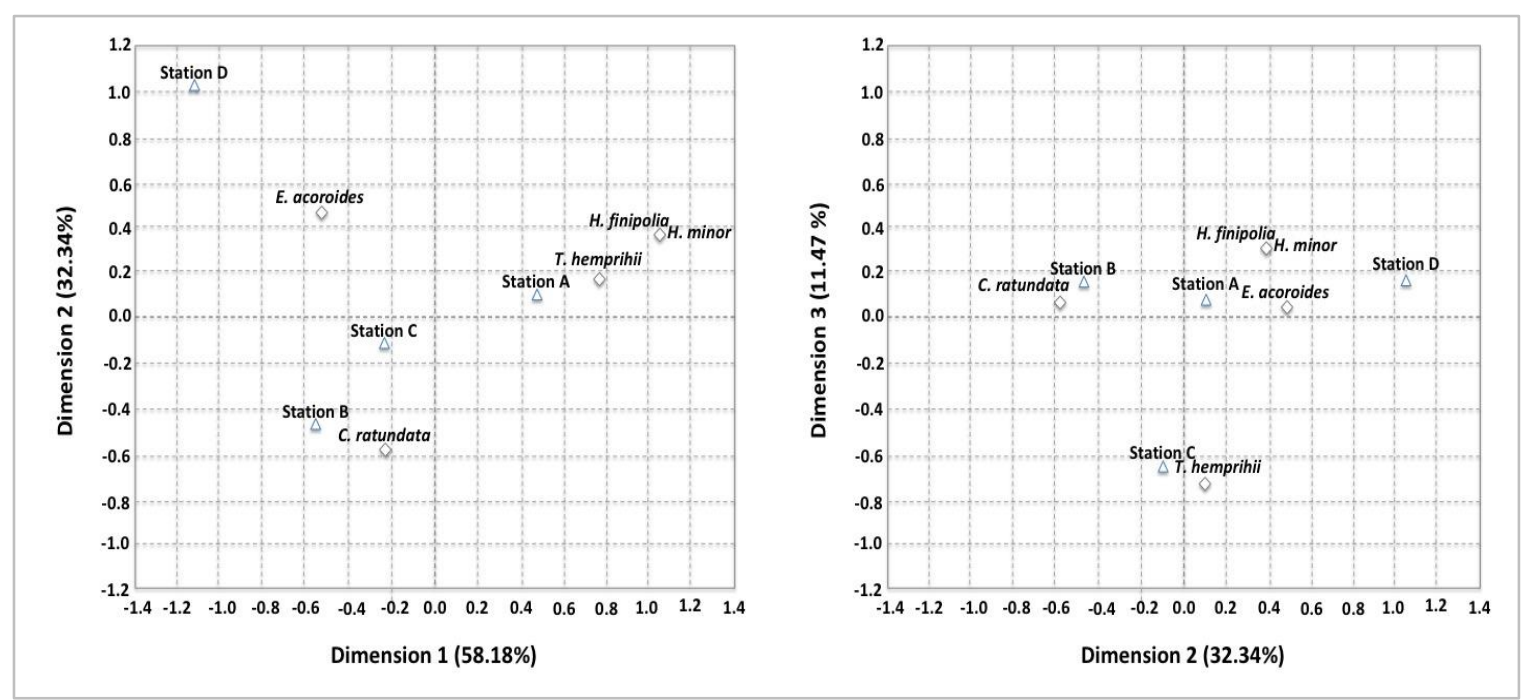

Gambar 3. Asosiasi sebaran spesies lamun berdasarkan Stasiun 
Tabel 2. Jumlah individu dan panjang total spesies Famili Carangidae

\begin{tabular}{|c|c|c|c|c|c|c|c|c|}
\hline \multirow{3}{*}{ Spesies } & \multicolumn{4}{|c|}{ Station A } & \multicolumn{4}{|c|}{ Station B } \\
\hline & \multicolumn{2}{|c|}{ Jumlah (indv./hari) } & \multicolumn{2}{|c|}{ Panjang total $(\mathrm{cm})$} & \multicolumn{2}{|c|}{ Jumlah (indv./hari) } & \multicolumn{2}{|c|}{ Panjang total $(\mathrm{cm})$} \\
\hline & Kisaran & $\operatorname{Rerata}( \pm S D)$ & Kisaran & $\operatorname{Rerata}( \pm S D)$ & Kisaran & $\operatorname{Rerata}( \pm S D)$ & Kisaran & $\operatorname{Rerata}( \pm S D)$ \\
\hline Alectis indicus & $0-1$ & $1 \pm 0,6$ & 4,7 & $4,7 \pm 0$ & 0 & $0 \pm 0,0$ & 0 & $0 \pm 0$ \\
\hline Carangoides ferdau & $1-4$ & $3 \pm 1,7$ & $10,7-14,5$ & $12,9 \pm 0,4$ & $1-5$ & $4 \pm 6,4$ & $11-18,3$ & $14,8 \pm 2,2$ \\
\hline C. caeruleopinnatus & $0-1$ & $1 \pm 0,6$ & 0,78 & $0,7 \pm 0$ & 0 & $0 \pm 0,0$ & 0 & $0 \pm 0,0$ \\
\hline C. hedlandensis & $0-4$ & $2 \pm 2,3$ & $12,2-19,6$ & $14,5 \pm 3,4$ & 0 & $0 \pm 0,0$ & 0 & $0 \pm 0$ \\
\hline Caranx sexfasciatus & 0 & $0 \pm 0$ & 0 & $0 \pm 0$ & 0 & $0 \pm 0,0$ & 0 & $0 \pm 0$ \\
\hline Pantolobus radiatus & 0 & $0 \pm 0$ & 0 & $0 \pm 0$ & $0-1$ & $1 \pm 6,4$ & 9,2 & $9,2 \pm 0$ \\
\hline Scomberoides tala & $0-1$ & $1 \pm 0,6$ & $17,5-27,5$ & $15 \pm 14$ & $0-1$ & $1 \pm 6,4$ & 41,5 & $4,5 \pm 0$ \\
\hline Selar boobs & 0 & $0 \pm 0$ & 0 & $0 \pm 0$ & 0 & $0 \pm 0,0$ & 0 & $0 \pm 0$ \\
\hline Selaroides leptolepis & $0-3$ & $2 \pm 1,7$ & $9,0-9,6$ & $9,3 \pm 0,3$ & $0-11$ & $4 \pm 6,4$ & $9,8-13,2$ & $11,3 \pm 1,2$ \\
\hline \multirow{3}{*}{ Spesies } & \multicolumn{4}{|c|}{ Station C } & \multicolumn{4}{|c|}{ Station D } \\
\hline & \multicolumn{2}{|c|}{ Jumlah (indv./hari) } & \multicolumn{2}{|c|}{ Panjang total $(\mathrm{cm})$} & \multicolumn{2}{|c|}{ Jumlah (indv./hari) } & \multicolumn{2}{|c|}{ Panjang total $(\mathrm{cm})$} \\
\hline & Kisar & $\operatorname{Rerata}( \pm S D)$ & Kisaran & $\operatorname{Rerata}( \pm S D)$ & Kisaran & $\operatorname{Rerata}( \pm S D)$ & Kisaran & $\operatorname{Rerata}( \pm S D)$ \\
\hline Alectis indicus & 0 & $0 \pm 0$ & 0 & $0 \pm 0$ & 0 & $0 \pm 0$ & 0 & $0 \pm 0$ \\
\hline Carangoides ferdau & 0 & $0 \pm 0$ & 0 & $0 \pm 0$ & $0-1$ & $1 \pm 1$ & $17,5-35$ & $26 \pm 12$ \\
\hline C. caeruleopinnatus & 0 & $0 \pm 0$ & 0 & $0 \pm 0$ & 0 & $0 \pm 0$ & 0 & $0 \pm 0,0$ \\
\hline C. hedlandensis & 0 & $0 \pm 0$ & 0 & $0 \pm 0$ & $0-1$ & $1 \pm 1$ & 9 & $9 \pm 0$ \\
\hline Caranx sexfasciatus & 0 & $0 \pm 0$ & 0 & $0 \pm 0$ & $0-1$ & $1 \pm 1$ & 8 & $8 \pm 0$ \\
\hline Pantolobus radiatus & 0 & $0 \pm 0$ & 0 & $0 \pm 0$ & 0 & $0 \pm 0$ & 0 & $0 \pm 0$ \\
\hline Scomberoides tala & $0-1$ & $1 \pm 0,6$ & $10,6-54,0$ & $32,3 \pm 30$ & $0-1$ & $1 \pm 0,6$ & 31 & $31 \pm 0$ \\
\hline Selar boobs & $0-18$ & $6 \pm 0,6$ & $13,8-15,5$ & $14,6 \pm 0,6$ & 0 & $0 \pm 0,0$ & 0 & $0 \pm 0$ \\
\hline Selaroides leptolepis & $0-8$ & $3 \pm 0,6$ & $12,4-14,1$ & $13,2 \pm 0,5$ & $0-1$ & $1 \pm 0,6$ & 6 & $6 \pm 0$ \\
\hline
\end{tabular}

(Sumber data : Survey 2020)

dan tiga genera yang memiliki persentase di bawah $3 \%$ yaitu Alectis, Caranx dan Pantolobus (Gambar 4 dan Gambar 5).

Berdasarkan persentase jumlah individu masing-masing spesies menunjukkan bahwa S. leptolepis $(28,6 \%)$ merupakan spesies dengan persentase tertinggi kemudian diikuti C. ferdau (Gambar 4). Berdasarkan Gambar 4 menunjukkan bahwa semua spesies dari genera tersebut adalah ikan yang bernilai ekonomis [15] dan ada 54,3\% merupakan genera yang termasuk ikan predator yang berukuran besar (Alectis, Carangoides, Caranx, Pantolobus dan Scomberoides) serta $45,7 \%$ yang termasuk ikan predator berukuran kecil (Selar dan Selaroides).

Berdasarkan sebaran spesies di masingmasing stasiun menunjukkan bahwa S. tala dan S. leptolepis ditemukan di empat stasiun (Stasiun A, B, C dan D), sedangkan C. 


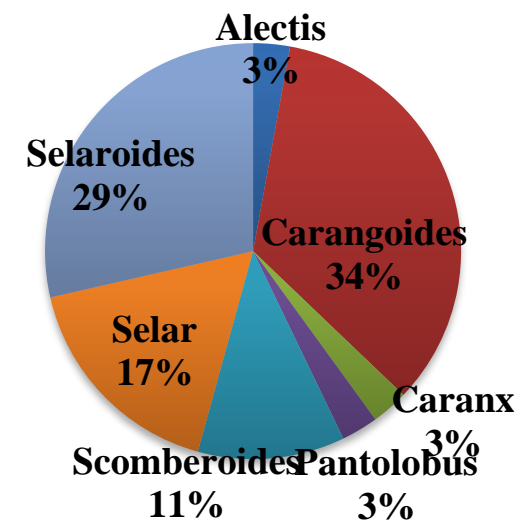

Gambar 4. Persentase jumlah individu berdasarkan genera

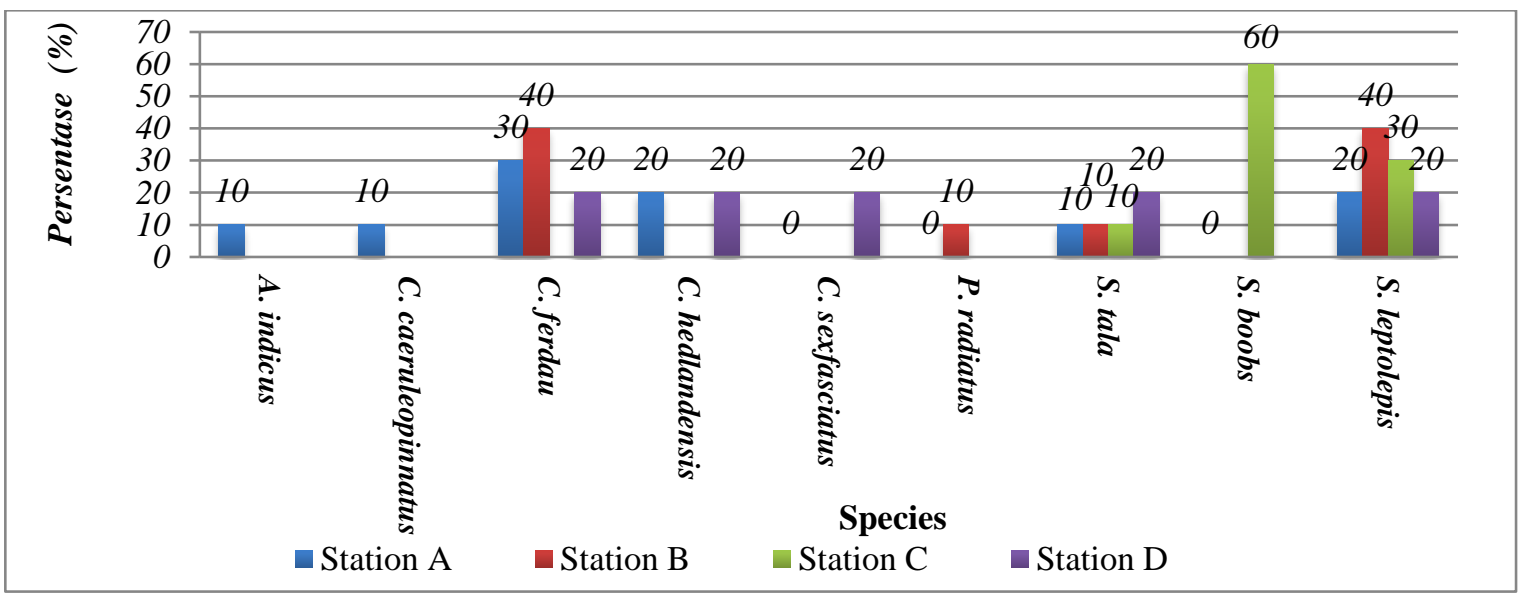

Gambar 5. Persentase sebaran spesies berdasarkan jumlah individu masing-masing stasiun

ferdau ditemukan di tiga Stasiun (Stasiun A, B dan D), kemudian spesies yang hanya ditemukan di dua stasiun yaitu $\mathrm{C}$. hedlandensis (Stasiun A dan D) sedangkan spesies yang hanya ditemukan di satu stasiun yaitu A. indicus, C. caeruleopinnatus cenderung hanya ditemukan pada Stasiun A, sedangkan $\mathrm{P}$. radiatus cenderung hanya ditemukan di Stasiun B, kemudian S. boobs cenderung hanya ditemukan di Stasiun $\mathrm{C}$ dan C. sexfasciatus cenderung hanya ditemukan di Stasiun D (Gambar 5). Kondisi demikian menunjukkan bahwa sebaran $\mathrm{S}$. tala dan S. leptolepis cenderung ditemukan pada empat karakteristik padang lamun yang berbeda, sedangkan sebaran $\mathrm{C}$. hedlandensis cenderung ditemukan pada dua karakteristik padang lamun yang berbeda dan A. indicus, C. caeruleopinnatus, P. radiatus, S. boobs dan C. sexfasciatus ditemukan pada satu karakteristik padang lamun tertentu.

Berdasarkan Gambar 5. menunjukkan bahwa di Stasiun A genera Carangoides merupakan genera yang dominan $(60 \%)$ yang terdiri dari C. ferdau (30 \%) kemudian C. hedlandensis dan S. leptolepis masingmasing $20 \%$. Stasiun B terdapat 2 genera yang dominan yaitu Carangoides (C. ferdau : $40 \%$ ) dan Selaroides (S. leptolepis :40 \%). Stasiun $\mathrm{C}$ terdapat 1 genera yang dominan yaitu Selar (S. boobs : $60 \%$ ), kemudian Stasiun D terdapat 1 genera yang dominan yaitu Carangoides (C. ferdau : $20 \%$ dan C. hedlandensis : $20 \%$ ). 
Berdasarkan persentase spesies menunjukkan bahwa S. leptolepis merupakan spesies yang dominan ditemukan di padang lamun dan cenderung berkelompok dengan fluktuasi jumlah individu relatif kecil $( \pm 2,33)$ (Tabel 1), dan diikuti dengan $\mathrm{S}$. tala yang cenderung ditemukan di empat stasiun dengan rata-rata persentase mencapai $11.4 \%$. Ditemukannya S. leptolepis dan S. tala di padang lamun menunjukkan adanya kesamaan karakteristik padang lamun sebagai habitatnya dan dimungkinkan S. tala sebagai predator dari S. leptolepis, hal tersebut berkaitan degan karakteristik famili Carangidae yang merupakan pemangsa predator [10]. Adanya kecenderungan tersebut terlihat pula di Stasiun C bahwa jumlah individu $\mathrm{S}$. leptolepis relatif rendah namun meningkatnya jumlah individu $\mathrm{S}$. boobs yang memiliki bentuk dan warna tubuh yang serupa dengan S. leptolepis.

Panjang Total

Panjang total individu spesies yang tertangkap menunjukkan bahwa memiliki panjang total rata-rata lebih pendek daripada panjang maksimum (Gambar 6). Rasio panjang total rata-rata dengan panjang maksimum, khususnya A. indicus, C. caeruleopinnatus, C. ferdau, C. hedlandensis, C. sexfasciatus, P. radiatus dan S. tala berkisar 1:3 - 1:51, hal tersebut menunjukkan bahwa spesies tersebut cenderung dalam fase juvenil, namun kisaran panjang total S. tala di Stasiun C memiliki kisaran ratio $1: 7-1: 2( \pm 14,6)$ (Tabel1). Hal tersebut menunjukkan bahwa kehadiran S. tala di padang lamun tersebut hingga fase muda. Demikian pula rasio panjang total rata-rata $S$. boobs mencapai 1 : $2( \pm 1,7)$ yang menunjukkan bahwa kehadirannya di padang lamun cenderung pada fase muda, sedangkan rasio $\mathrm{S}$. leptolepis berkisar $1: 3,3-1: 2( \pm 0,52)$ menunjukkan kehadirannya di padang lamun cenderung dari fase juvenil hingga muda.

Berdasarkan Gambar 6 menunjukkan pula bahwa panjang total rata-rata $\mathrm{S}$. tala cenderung lebih panjang dari pada $\mathrm{S}$. leptolepis dengan rasio panjang total tersebut $1: 2$, hal tersebut menunjukkan bahwa peluang S. leptolepis dimangsa S. tala cenderung besar. Berbeda halnya dengan panjang total rata-rata A. indicus, $\mathrm{C}$. caeruleopinnatus, C. hedlandensis, $\mathrm{C}$. sexfasciatus, dan P. radiatus yang cenderung lebih kecil daripada $\mathrm{S}$. tala namun kelima spesies tersebut memiliki bentuk tubuh kompres.

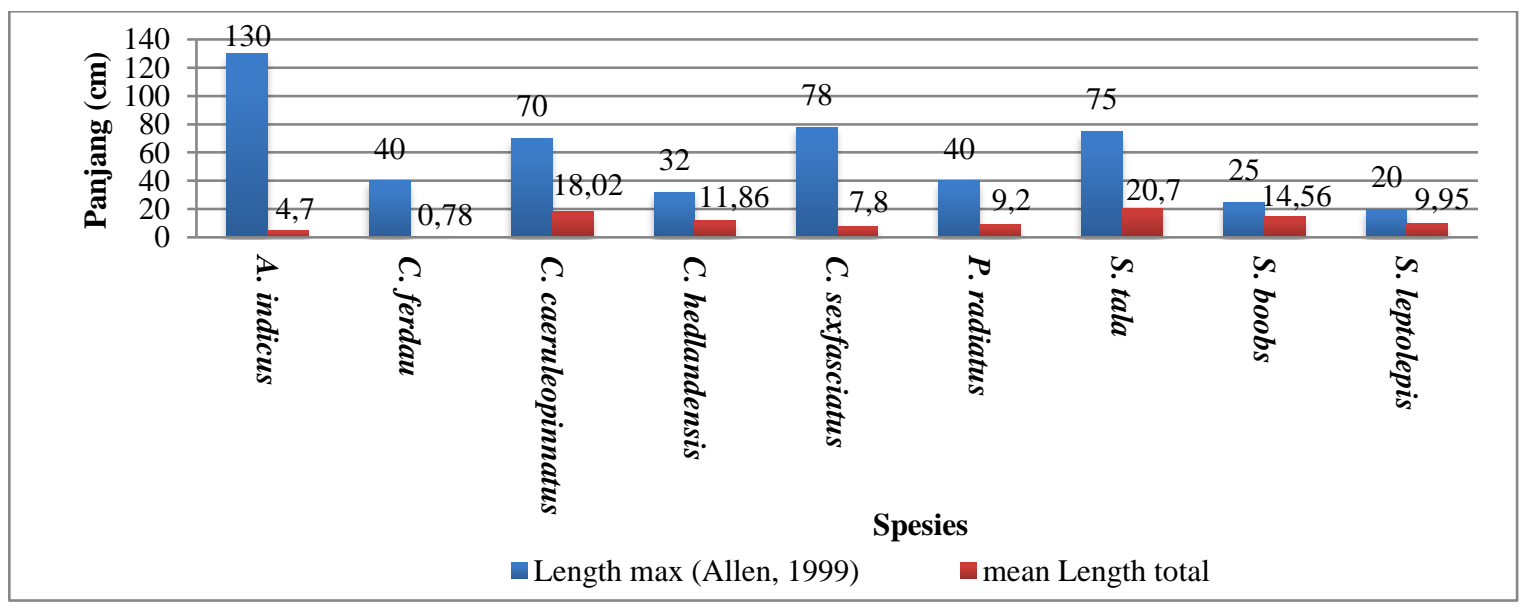

Gambar 6. Panjang total rata-rata spesies dan panjang maksimum 


\section{Kualitas Fisika-Kimia Perairan}

Suhu perairan di bagian utara Kota Bontang berkisar $28,71-32,34{ }^{\circ} \mathrm{C}$ dengan rata-rata $30,73( \pm 1,17){ }^{\circ} \mathrm{C}$, kisaran dan ratarata tersebut menunjukkan fluktuasi suhu relatif kecil (Tabel 3). Berdasarkan stasiun menunjukkan bahwa Stasiun A dan Stasiun C cenderung memiliki kisaran dan rata-rata suhu dan fluktuasi suhu lebih tinggi daripada Stasiun B dan Stasiun D (Tabel 3). Kisaran dan rata-rata suhu perairan tersebut pada kisaran yang layak dalam mendukung kehidupan lamun, hal tersebut tergambar dari kisaran suhu optimal untuk fotosintesis $H$. Tabel 3. Parameter fisika-kimia perairan di masing-masing stasiun.

\begin{tabular}{|c|c|c|c|c|c|}
\hline \multirow{2}{*}{ Variabel } & \multicolumn{2}{|c|}{ Stasiun A } & \multicolumn{2}{|c|}{ Stasiun B } & \multirow[t]{2}{*}{ Baku Mutu* } \\
\hline & Kisaran & $\operatorname{Rerata}( \pm \mathrm{SD})$ & Kisaran & $\operatorname{Rerata}( \pm \mathrm{SD})$ & \\
\hline Suhu $\left({ }^{\circ} \mathrm{C}\right)$ & $29,57-32,34$ & $31,04 \pm 1,39$ & $29,3-31,0$ & $30,15 \pm 0,88$ & $28-32$ \\
\hline Salinitas (\%o) & $30,27-32,15$ & $31,21 \pm 0,94$ & $29,1-31,30$ & $30,20 \pm 1,10$ & \\
\hline $\mathrm{pH}$ & $7,3-7,6$ & $7,46 \pm 0,16$ & $6,8-7,15$ & $6,99 \pm 0,19$ & $7-8,5$ \\
\hline Kekeruhan (NTU) & $37-51$ & $45,33 \pm 7,37$ & $83,1-87,46$ & $85,61 \pm 2,24$ & $<5 \mathrm{NTU}$ \\
\hline \multirow{2}{*}{ Variabel } & \multicolumn{2}{|c|}{ Stasiun $\mathrm{C}$} & \multicolumn{2}{|c|}{ Stasiun D } & \\
\hline & Kisaran & $\operatorname{Rerata}( \pm \mathrm{SD})$ & Kisaran & $\operatorname{Rerata}( \pm \mathrm{SD})$ & \\
\hline Suhu $\left({ }^{\circ} \mathrm{C}\right)$ & $30,26-33,11$ & $31,63 \pm 1,43$ & $28,71-29,46$ & $30,09 \pm 0,97$ & $28-32$ \\
\hline Salinitas (\%o) & $31,27-31,76$ & $31,52 \pm 0,25$ & $27,85-29,33$ & $28,65 \pm 0,75$ & \\
\hline $\mathrm{pH}$ & $7,33-7,52$ & $7,44 \pm 0,10$ & $6,32-7,13$ & $6,67 \pm 0,41$ & $7-8,5$ \\
\hline Kekeruhan (NTU) & $27,16-29,21$ & $28,24 \pm 1,03$ & $53,74-55,17$ & $54,48 \pm 0,72$ & $<5 \mathrm{NTU}$ \\
\hline
\end{tabular}

* KEPMEN LH No. 51/2004 tentang Baku Mutu Air Laut untuk Biota laut

uninervis dan C. serrulata yaitu $31-35{ }^{\circ} \mathrm{C}$ [29].

Salinitas berkisar $27,85-32,15 \%$ dengan rata-rata $30,39( \pm 0,76) \%$, kisaran dan rata-rata tersebut menunjukkan fluktuasi salinitas relatif kecil (Tabel 3). Berdasarkan stasiun menunjukkan bahwa Stasiun A dan Stasiun $\mathrm{C}$ cenderung memiliki kisaran dan rata-rata salinitas dan fluktuasi salinitas lebih rendah daripada Stasiun B dan Stasiun D (Tabel 3). Kisaran dan rata-rata salinitas tersebut menunjukkan bahwa keempat padang lamun tersebut pada kisaran yang layak dalam mendukung kehidupan lamun, karena lamun memiliki toleransi salinitas yang besar yaitu 9 - $37 \%$ [30] dan pertumbuhan daun optimum pada Posidonia oceanica berkisar $25-39 \%$ [31].

Keasaman $(\mathrm{pH})$ perairan berkisar 6,32 7,60 dengan rata-rata $7,14( \pm 0,22){ }^{\circ} \mathrm{C}$, kisaran dan rata-rata tersebut menunjukkan fluktuasi $\mathrm{pH}$ relatif kecil. Berdasarkan stasiun menunjukkan bahwa Stasiun A dan Stasiun C cenderung memiliki kisaran dan rata-rata $\mathrm{pH}$ dan fluktuasi $\mathrm{pH}$ lebih rendah daripada Stasiun B dan Stasiun D (Tabel 3). Kondisi demikian terjadi karena Stasiun A dan Stasiun C merupakan hamparan gusung dimana padang lamun berasosiasi dengan hamparan pasir, batu karang dan terumbu karang serta adanya kecenderungan massa air dominan dari Selat Makassar, sedangkan Stasiun B merupakan padang lamun yang berasosiasi dengan hutan mangrove dan massa air dari muara sungai dan Stasiun D merupakan padang lamun yang berasosiasi dengan muara sungai. Berdasarkan rata-rata dan fluktuasi $\mathrm{pH}$ di perairan yang masih dipengaruhi estuari tersebut masih dalam fluktuasi alami yaitu 0,2 unit dan adanya kisaran $\mathrm{pH}$ demikian didorong oleh $\mathrm{pH}$ spasial padang lamun akibat metabolisme vegetasi [32].

Kekeruhan perairan berkisar 27,16 87,46 NTU dengan rata-rata $53,41( \pm 2,84)$ NTU, kisaran dan rata-rata tersebut menunjukkan fluktuasi kekeruhan relatif besar (Tabel 3). Berdasarkan stasiun menunjukkan bahwa Stasiun A memiliki fluktuasi kekeruhan paling tinggi dengan kisaran 37-51 NTU dengan rata-rata 45,33( $\pm 7,37)$ NTU, sedangkan Stasiun C memiliki fluktuasi kekeruhan lebih rendah dan demikian pula untuk Stasiun B dan Stasiun D dari pada Stasiun A (Tabel 3). Adanya kecenderungan tingginya flutuasi kekeruhan di Stasiun A dimungkinkan dekatnya dengan muara sungai Tanjung Limau. Lebih rendahnya ketiga stasiun lainnya dari pada Stasiun A, menunjukkan bahwa kondisi massa air yang membawa 
komponen kekeruhan di perairan tersebut cenderung terjadi terus menerus. Kisaran dan rata-rata kekeruhan tersebut menunjukkan bahwa keempat padang lamun tersebut pada kisaran yang telah melampaui nilai kekeruhan bagi kehidupan lamun berdasarkan KEPMEN LH No. 51/2004 tentang Baku Mutu Air Laut untuk Biota Laut dan kondisi tersebut menunjukkan bahwa padang lamun tersebut tertekan secara ekologis.

Berdasarkan Gambar 7 menunjukkan bahwa karakteristik kualitas air di masingmasing stasiun yang terinformasi sebesar $100 \%$ yang terdiri dari Faktor 1 sebesar

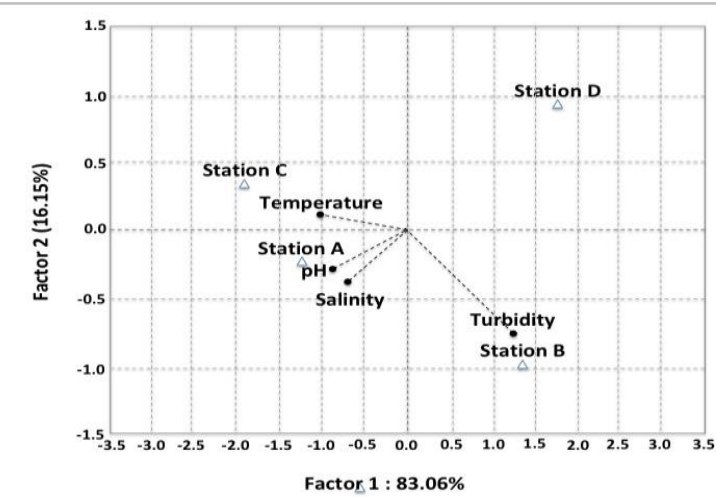

Gambar 7. Sebaran karakteristik fisika-kimia perairan berdasarkan stasiun
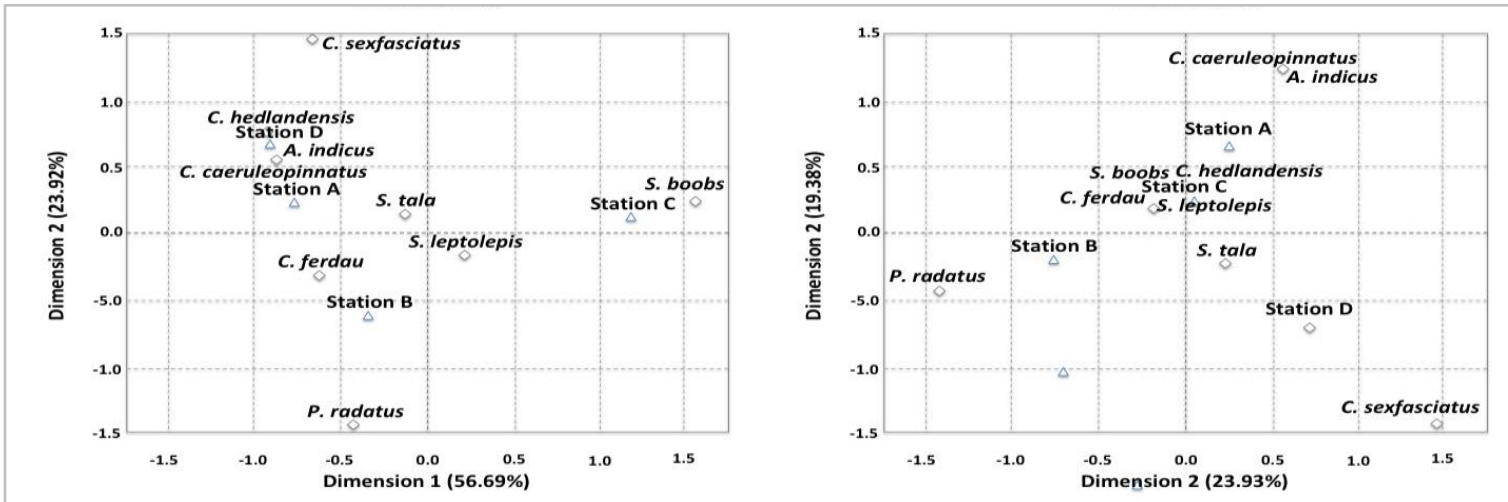

Gambar 8. Asosiasi sebaran jumlah individu spesies dari Famili Carangidae berdasarkan Stasiun.

Faktor 2 sebesar 16,15\% dan Faktor 3 sebesar $0,97 \%$. Karaktersitik Stasiun A dicirikan oleh $\mathrm{pH}$ yang tinggi, Stasiun B dicirikan oleh kekeruhan yang tinggi, Stasiun C dicirikan oleh salinitas yang tinggi dan Stasiun D tidak dicirikan oleh variabel fisika-kimia perairan yang diukur.

\section{Asosiasi Famili Carangidae di padang lamun.}

Berdasarkan Gambar 8 menunjukkan bahwa A. indicus dan C. caeruleopinnatus berasosiasi positif terhadap karakteristik sebaran fisika-kimia perairan dan spesies lamun di Stasiun A yaitu $\mathrm{pH}$ yang tinggi dan suhu yang rendah serta tingginya kerapatan $H$. pinifolia dan H. minor (Gambar 3 dan Gambar 7). Kondisi demikian menunjukkan bahwa $A$. indicus dan C. caeruleopinnatus cenderung di temukan pada kisaran $\mathrm{pH}$ 7,3-7,6 dengan ratarata $7,46( \pm 0,16)$ berasosiasi erat dengan $H$. pinifolia $(\mathrm{r}=1,00 ; \mathrm{KR}=100 \%)$ dan $\mathrm{H}$. minor $(\mathrm{r}=1,00 ; \mathrm{KR}=100 \%)$. Hal tersebut menunjukkan bahwa A. indicus dan $C$. caeruleopinnatus pada fase juvenil atau muda cenderung menjadikan padang lamun yang disusun oleh $H$. pinifolia dan $H$. minor sebagai habitatnya.

Asosiasi $P$. radatus dan $S$. leptolepis berasosiasi dengan karakteristik sebaran fisika-kimia perairan dan spesies lamun di Stasiun B yaitu dengan nilai kekeruhan yang tinggi dan kerapatan $C$. ratundata. Kondisi demikian menunjukkan bahwa $P$. radatus dan S. leptolepis cenderung ditemukan pada kisaran kekeruhan 83,12-87,46 NTU dengan rata-rata $85,61( \pm 2,24)$ NTU dan berasosiasi erat dengan tegakan $C$. ratundata (P. radatus : 
$\mathrm{r}=0,83 ; \mathrm{KR}=68,89 \%$ dan S. leptolepis $: \mathrm{r}=$ $0,48 ; \quad \mathrm{KR}=23,04 \%)$. Hal tersebut menunjukkan bahwa $\mathrm{P}$. radatus dan $S$. leptolepis pada fase juvenil atau muda cenderung menjadikan padang lamun yang disusun oleh $C$. ratundata sebagai habitatnya.

Asosiasi S. boobs berasosiasi positif terhadap karakteristik sebaran fisika-kimia perairan dan spesies lamun di Stasiun $C$ yaitu dengan salinitas yang tinggi dan kerapatan $\mathrm{T}$. hemprichii. Kondisi demikian menunjukkan bahwa $S$. boobs cenderung ditemukan pada kisaran salinitas 31,27-31,76 \% dengan ratarata $31,52( \pm 0,25) \%$ dan berasosiasi erat dengan $T$. hemprichii $(\mathrm{r}=0,28 ; \mathrm{KR}=7,84 \%)$. Hal tersebut menunjukkan bahwa S. boobs pada fase juvenil atau muda cenderung menjadikan padang lamun yang disusun oleh T. hemprichii sebagai habitatnya.

Asosiasi C. hedlandensis berasosiasi positif terhadap karakteristik sebaran fisikakimia perairan Stasiun D yang secara khsusus tidak dicirikan oleh variabel fisika-kimia perairan yang diukur serta E. acoroides. Kondisi demikian menunjukkan bahwa $C$. hedlandensis cenderung di temukan pada kisaran suhu $28,71-29,46{ }^{\circ} \mathrm{C}$ dengan rata-rata $30,09( \pm 0,97) \quad{ }^{\circ} \mathrm{C}$, salinitas berkisar 27,85 $29,33 \%$ dengan rata-rata $28,65( \pm 0,75) \%$, dan kisaran $\mathrm{pH}$ 6,32 - 7,13 dangan rata-rata $6,67( \pm 0,41)$ sedangkan kekeruhan berkisar 53,74 - 55,17 NTU dengan rata-rata 54,48 $( \pm 0,72)$ NTU maupun berasosiasi erat dengan E. acoroides $(\mathrm{r}=0,40 ; \mathrm{KD} ; 16,0 \%)$. Hal tersebut menunjukkan bahwa $C$. hedlandensis pada fase juvenil atau muda cenderung menjadikan padang lamun yang disusun oleh E. acoroides sebagai habitatnya.

Asosiasi C. sexfasciatus dan $S$. tala cenderung ditemukan pada kondisi variabel fisika-kimia perairan dengan $\mathrm{pH}$ yang rendah dan suhu yang lebih tinggi dari Stasiun A, sedangkan C. ferdau cenderung ditemukan pada kisaran salinitas yang lebih rendah dari kisaran salinitas di Stasiun C. Kisaran $\mathrm{pH}$ perairan yang cenderung ditemukannya $\mathrm{C}$. sexfasciatus dan $S$. tala berkisar 6,32 - 7,52 dengan rata-rata 7,04 $( \pm 0,23)$ dan kisaran suhu $30,15-31,63{ }^{\circ} \mathrm{C}$ dengan rata-rata $30,63{ }^{\circ} \mathrm{C}$. Asosiasi $C$. ferdau cenderung ditemukan pada kondisi variabel kisaran dan rata salinitas yang rendah daripada kisaran dan rata-rata salinitas Stasiun C. Kisaran salinitas yang cenderung ditemukannya C. ferdau berkisar 28,66 -
$31,21 \%$ dengan rata-rata $30,02( \pm 1,08) \%$. Hal tersebut menunjukkan bahwa $C$. sexfasciatus, $C$. ferdau dan $S$. tala pada fase juvenil atau muda cenderung menjadikan padang lamun secara umum sebagai habitatnya.

\section{KESIMPULAN}

1. Padang lamun yang dominan disusun oleh $H$. pinifolia dan $H$. minor cenderung sebagai habitat dari A. indicus dan $\mathrm{C}$. caeruleopinnatus pada fase juvenil hingga muda.

2. Padang lamun yang dominan disusun oleh C. ratundata cenderung sebagai habitat dari $P$. radatus dan $S$. leptolepis pada fase juvenil hingga muda.

3. Padang lamun yang dominan disusun oleh $T$. hemprichii cenderung sebagai habitat dari $S$. boobs pada fase juvenil hingga muda.

4. Carangoides hedlandensis pada fase juvenil hingga muda cenderung menjadikan padang lamun yang disusun oleh E. acoroides sebagai habitatnya.

5. Padang lamun secara umum merupakan habitat dari $C$. sexfasciatus, $C$. ferdau dan $S$. tala pada fase juvenil hingga muda.

\section{UCAPAN TERIMA KASIH}

Ucapan terima kasih kepada Dekan Fakultas Perikanan dan Ilmu Kelautan Universitas Mulawarman yang telah memberikan pembiayaan penelitian melalui Hibah Penelitian Fakultas Tahun Anggaran 2020.

\section{DAFTAR PUSTAKA}

[1] J.D. Bell, A.S. Steffe, M. Westoby.

[5] P.L.A. Erftemeijer, G.R. Allen. "Fish Fauna of Seagrass Beds in South Sulawesi, Indonesia". Rac. West Aust. Mus. Volume 16 No.2, hal. 269 277. 1993.

[6] J.M. Carrol, B.J. Peterson. "Ecological trade-offs in seascape ecology: bay scallop survival and growth across a seagrass seascape". Landscape Ecol. Volume 28, hal. 1401-1413. April 2013. 
[7] C.M. Jones. "Can we Predict the Future: Juvenile Finfish and Their Seagrass Nurseries in the Chesapeake Bay. Contribution to the Themed Section: 'The Value of Coastal Habitats for Exploited Species'.” ICES Journal of Marine Science, Volume 71 No.3, hal. 681-688. April 2013.

[8] C. Cucio, A.H. Engelen, R. Costa, G. Muyzer. "Rhizosphere Microbiomes of European Seagrasses Are Selected by the Plant, But Are Not Species Specific." Frontiers in Microbiology. 7 (440), hal. 1-14. Maret 2016.

[9] A. Irawan, Supriharyono, J. Hutabarat, Ambariyanto."Threat of small scale capture fisheries on the fish biodiversity in seagrass beds of Bontang, East Kalimantan, Indonesia." AACL Bioflux, Volume 12 No.6, hal. 22862297. Des 2019.

[10] A. Blandon, P.S.E. zu Ermgassen. "Quantitative Estimate of Commercial Fish Enhancement by Seagrass Habitat in Southern Australia." Estuarine, Coastal and Shelf Science. 141, hal. 18. Maret 2014.

[11] R.R. Honebrink. "A review of the biology of the family Carangidae, with emphasis on species found in Hawaiian waters." DAR Technical Report 20-01. Okt.2000.

[12] M. Wright, G. Sparrow. "Marine Life From Tropical Fish to Mighty Shark. Revised edition published." Amber Books Ltd. United Kingdom, hal. 320 . 2016.

[13] W.F. Smith-Vaniz. "Carangidae. Jacks and scads (bumpers, pompanos, leatherjacks, amberjacks, pilotfishes, "Location of seagrass beds in estuaries: effects on associated fish and decapods." Journal of Experimental Marine Biology and Ecology Volume 122 No. 2, hal. 127-146. Okt. 1988

[2] S. Nuraini, E.C. Carballo, W.L.T. van Densen, M.A.M. Machiels, H.J. Lindeboom, L.A.J. Nagelkerke.. "Utilization of seagrass habitats by juvenile groupers and snappers in Banten Bay, Banten Province, Indonesia”. Hydrobiologia Volume 591 No. 1, hal. 85-98. 2007.
[3] K. Honda, Y. Nakamura, M. Nakaoka, W.H. Uy, M.D. Fortes. "Habitat Use by Fishes in Coral Reefs, Seagrass Beds and Mangrove Habitats in the Philippines". PLoS ONE Volume 8 No.8 : e65735. Agustus 2013.

[4] R.G. Coles, W.J.L. Long, R.A. Watson, K.J. Derbyshire. "Distribution of Seagrasses, and Their Fish and Penaeid Prawn Communities, in Cairns Harbour, a Tropical Estuary, Northern Queensland, Australia." Aust. J. Mar. Freshwater Res. 44, hal. 193-210. 1993. rudderfishes)”. p. 1426-1468. In K.E. Carpenter (ed.) FAO species identification guide for fishery purposes. The living marine resources of the Western Central Atlantic. Vol. 3: Bony fishes part 2 (Opistognathidae to Molidae), sea turtles and marine mammals. 2003.

[14] A. Nurfiarini, M.M. Kamal, L. Adeianto, S.B. Susilo. "Keanekaragaman Hayati Sumberdaya Ikan di Estuari Segara Anakan, Cilacap Jawa Tengah". BAWAL, Volume 7 No.1, hal. 25-34. April 2015.

[15] G. Allen. "Marine Fisher of South-East Asia." Periplus Edition. Indonesia. 292 hal. 1999.

[16] S.J. Campbell, T. Kartawijaya, E.K. Sabarini. "Connectivity in Reef Fish Assemblages between Seagrass and Coral Reef Habitats." Aquat Biol. 13, hal. 65-77. 2011.

[17] A. Irawan, Supriharyono, J. Hutabarat, Ambariyanto. "Seagrass beds as the buffer zone for fish biodiversity in coastal water of Bontang City, East Kalimantan, Indonesia." Biodiversitas Volume 19 No.3, hal. 1044-1053. Mei 2018.

[18] National Working Group on Ecosystem Approach to Fisheries Management (NEG-EAFM) dan Direktorat Sumberdaya Ikan Kementerian Kelautandan Perikanan Republik Indonesia (KKP-RI). "Modul : Indikator untuk Pengelolaan Perikanan dengan Pendekatan Ekosistem (Ecosystem Approach to Fisheries Management)." Kerjasama NEGEAFM) dan Direktorat Sumberdaya Ikan-KKP RI. Jakarta. 205 hal. 2014. 
[19] S. English, C. Wilkinson, V. Baker. "Survey Mannual For Tropical Marine Resources." Townville, Australia. ASEAN-Australia Marine Science Project : Living Coastal Resources by Australian Institute Of Marine Science. 368 hal. 1994.

[20] C. den Hartog. "The Sea-grasses of the word." North-Holland Publishing Company-Amsterdam. 275 hal. 1970.

[21] J. Kuo, C. den Hartog. Seagrass "Morphology, Anatomy, and Ultrastructure. In Seagrasses : Biology, Ecology and Conservation": A.W.D. Larkum, R.J. Orth and C.M. Duarte (editor). Springer. 676 hal. 2006.

[22] D.M. Fortes. "Taxsonomy and Distribution of Seagrasses in the ASEAN Region." in Study No. 6 Seagrasses Resources in Southeast Asia. UNESCO - Jakarta (Rostsea). 15-58 hal. 1993.

[23] T. Tomascik, Mah AJ, A. Nontji, dan M.K.Moosa. "The Ecology of the Indonesia." Part II. Singapore. Published by Periplus Editions Ltd., hal 643-1388. 1997.

[24] G.I. Setiabudi, D.G. Bengen, E. Effendi, O.K. Radjasa. "The Community Structure of Phytoplankton in Seagrass Ecosyatem and its Relaionship with Evnveronmental Characterstics." Biosaintifika, Volume 8 No. 3, hal. 257-269. Des 2016.

[25] K. Kasim, S. Triharyuni, A. Wujdi. "Hubungan Ikan Pelagis dengan Konsentrasi Klorifil-a di Laut Jawa." BAWAL. Volume 6 No.1, hal. 21-29. April 2014.

[26] S. Fakhri, I. Riyantini, D. Juliandri, H. Hamdani. "Korelasi Kelimpahan Ikan Baronang (Siganus Spp) dengan Ekosistem Padang Lamun di Perairan Pulau Pramuka Taman Nasional Kepulauan Seribu". Jurnal Perikanan Kelautan. Volume VII No.1, hal. 165171. Juni 2016.

[27] Z. Abdullah, Yusrizal, S. Syamsuddin. "Analisis Suhu Permukaan Laut dan klorofil-a untuk Mengetahui Potensi Ikan di dalam Fhising Ground Purse Seine Menggunakan Citra Satelit Aqua Modis Level 3." Jurnal Kelautan dan Perikanan Terapan. Volume 1 No.1, hal 38-45. Juni 2018.
[28] P.L. Lin, K.T. Shao. "A Review of the Carangid Fishes (Family Carangidae) from Taiwan with Descriptions of Four New Records." Zoological Studies, Volume 38 No. 1, hal. 33-68. Okt. 1999.

[29] C.J. Collier, Y.X. Ow, L. Langlois, S. Uthicke S, C.L. Johansson, K.R. O'Brien, V. Hrebien, M.P. Adams. "Optimum Temperatures for Net Primary Productivity of Three Tropical Seagrass Species." Front. Plant Sci. 8(1446), hal.1-14. Agustus 2017.

[30] H. Kirman, D.I. Walker. "Regional Studies-Western Australian Seagrass." in Larkum AWD, McComb AJ, Shepherd SA, editor. Biology of Seagrasses: A treatise on the biology of seagrasses with special refrence to the Australian regon. Aquatic Plan Studies 2. Amsterdam: Elsevier, hal. 157-181. 1989.

[31] Y. Ferná ndez - Torquemada, J.L. Sa' nchez-Lizaso. "Effects of salinity on leaf growth and survival of the Mediterranean seagrass Posidonia oceanica (L.) Delile." Journal of Experimental Marine Biology and Ecology. Volume 320 No. 1, hal. 5763. Juni 2005. [31] Y. Ferna ndez Torquemada, J.L. Sa nchez-Lizaso. "Effects of salinity on leaf growth and survival of the Mediterranean seagrass Posidonia oceanica (L.) Delile." Journal of Experimental Marine Biology and Ecology. Volume 320 No. 1, hal. 57-63. Juni 2005.

[32] R.K. James, M.M. van Katwijk, B.I. van Tussenbroek, T. van de Heide, H.A. Dijkstra, R.M. van Westen, J.D. Pietrzak, A.S. Candy, R. Klees, R.E.M. Riva, C.D. Slobbe, C.A. Katsman, P.M.J. Herman, T.J. Bouma. "Water motion and vegetation control the $\mathrm{pH}$ dynamics in seagrass-dominated bays." Limnol. Oceanogr. 65, hal. 349-362. 2020. 